\title{
THE DEVELOPMENT OF ROMAN IMPERIAL ATTITUDES AND THE IBERIAN WARS (*)
}

Rome's behavior in the Iberian Wars and its ideological influence at home is studied. The author states that these wars abroad provided an important motivation for the rethinking of Roman imperial policy.

Over forty years ago Matthias Gelzer elucidated so well the first stirrings of a Roman historical consciousness by examining the efforts of Fabius Pictor to justify the extension of Roman influence in an epic unfolding of Roman uirtus ${ }^{1}$. Only the heavy responsibility of fides to its citizens and allies had drawn it beyond the borders of its city-state to a position of prominence in the western Mediterranean. Fabius and his annalistic successors cast their narrative in terms certainly most attractive to its intended audience - the Hellenic worid. Previous Hellenic accusations of Roman barbarisn, cruelty and treachery faded in the repeated accounts of Roman moral excellence ${ }^{2}$. For the next half century this imperialistic apologetic evidenced few changes, but with the onset of the Third Macedonian War, Roman policy was marked by significant departures from the standard tradition. Perseus became the first monarchical sacrifice to a Roman triumph. The kingdom of Macedonia ceased to exist. C. Popilius Laenas not only frustrated but humiliated Seleucid ambitions in Egypt. The ferocity with which Rome handled Pergamum and Rhodes bore a poor resemblance to the same Rome that agonized over the moral issues of sending aid to Messana in 264. But nowhere did the signs of change seem more apparent than in the destruction of Corinth and Carthage in $I_{4} 6$. The

${ }^{*}$ ) This paper was read at the VI International Congress of Classical Stu dies in Madrid on September 3, 1974.

1 Matthias Gelzer, "Römische Politik bei Fabius Pictor», Hermes 68, I933, pp. 129-166.

2 Ibid., pp. r30 ff. For examples of the accusations see Pol. XI 5, 6; Livy XXXI 29, I2. 
discussion on that subject has been lengthy as well as illuminating. Nor only did this date mark a significant transition in Roman imperial policy, but it also soon became for many historians the beginning of the consequent collapse of the republic ${ }^{1}$.

However, one important element in this transition han been surprisingly neglected, especially by modern historians, and that is the effect of Rome's lengthy and frustrating wars in Iberia upon its imperial Weltanschauung ${ }^{2}$. This neglect is indeed curious, for a number of Roman historians, in discussing the highpoints of Roman imperialistic efforts, link together Corinth, Carthage a $\mathrm{nd} \mathrm{Numantia}$ as the milestones of a new era ${ }^{3}$. Historians heve never failed to catalogue the changes produced in Rome as a result of the Iberian Wars ${ }^{4}$. In order to facilitate command changes in Iberia, Roman consuls now took office in January. Resistance to the draft dramatically underscored the social rift growing in Italy. The constitution was manipulated to allow otherwise illegal commands for M. Claudius Marcellus and Scipio Aemilanus. In addition, tribunician activity was stepped up to protect the people from the severity of increased conscription; while in the field Roman commanders were called upon more and more to assume the role of diplomat and negotiator, a role that was often uncomfortable and cumbersome. It should not be surprising, then, that the Iberian Wars should leave their mark on Roman historiography. In Roman tradition Numantia came to mark one of Rome's great mi-

1 Although not exhaustive, the following list is representative of the major arguments. Matthias Gelzer, "Nasicas Widerspruch gegen die Zerstörung Karthagos", Kleine Schriften II, pp. 39-72; H. H. Scullard, "Scipio Aemilianus and Roman Politics», JRS 50, I960, pp. 59-74; F. W. Walbank, "Political Morality and the Friends of Scipion, JRS 55, 1965, pp. I-16; W. Hoffmann, "Die römische Politik des 2. Jahrhunderts und das Ende Karthagos», Historia 9, 1960, pp. 309$344 ; H$. Volkmann, "Griechische Rhetorik oder römischen Politik», Hermes 82, 1954, pp. 465-476. F. Hampl, "Römische Politik in republikanischer Zeit und das Problem des Sittenverfalls", $H Z$ I88, r959, pp. 497-525.

2 W. Hoffmann, for example, detects a change in Roman policy going back to Pydna and traces it up to the Third Punic War, but unfortunately he completely fails to consider the wars in Iberia as illustrative of, not to mention formative in, such a change in policy: "Die römische Politik des 2. Jahrhunderts und das Ende Karthagos?, p. 332 ff.

s Florus I 33, 17; 34; Orosius V 8; Cic., Phil. IV 5, 13; Hor., Odes II 12. Gelzer also joins in lumping together this imperial troika: «Nasicas Widerspruch gegen die Zerstörung Karthagos", p. 65.

- For example see J. M. Blázquez, "El Impacto de la Conquista de Hispania en Roma (154-83 a. C.) \#, Klio 4r, 1963, pp. 168-186. A. E. Astin, Scipio Aemilianus (London: Oxford University Press), pp. 4I ff. 
litary achievements ${ }^{1}$. And yet Numatia was little more than the brutal and pitiful end of what must be considered one of the sorriest records of any Roman imperial effort.

The earlier annalists had proclaimed the mildness of Roman treatment of defeated enemies ${ }^{2}$, but the repeated massacres of Lusitanian and Celtiberian tribes contrasted poorly to that proclamation. Roman denials of any designs on imperial aggrandizement, like that of T. Quinctius Flaminius at the Isthmian games, stood contradicted by the continued seizure of Iberian territory. Polybius' narrative of the energy that continually put new fleets to sea against the Carthaginians in the First Punic War was now overshadowed by the paralyzing fear that now gripped new recruits and officers alike, who refused to go to Iberia. Even as late as the eve ef the Third Punic War, Roman apologists argued that Rome was entirely justified in going to war against Carthage because the latter had continually broken treaties with them ${ }^{3}$. And yet this argument was offered at the same time Rome blatantly broke treaties secured by $Q$. Fabius Maximus Servilianus, $Q$. Pompeius Aulus and C. Hostilius Mancinus in Iberia ${ }^{4}$.

Obviously the old annalistic tradition could not suffice to explain Rome's involvement in Iberia. New means of justification or simply adjustments to Roman policy had to be made ${ }^{5}$. This of course did not mean that the annalistic tradition ceased, but it did find itself hardpressed by the new explanations ${ }^{6}$. Although somewhat simplified, for the sake of discussion, the rival traditions can be divided into three primary categories; the older annalistic tradition, the Polybian and the Stoic-Posidonian.

1 See n. 3, page 4 ro.

2 Scipio Africanus used Iberia as a showcase of Roman diplomacy and the careful handling of treaties: cf. Pol. XV I7, 4; XXI 4, I0-I 4; discused by Gelzer, "Nasicas Widerspruch gegen die Zerstörung Karthagos", p. 56.

3 Ibid., $46 \mathrm{f}$.

- F. W. Walbank argues that Polybius accused the Romans of using "deceit and frauds in their foreign conquests, noting a significant change after Pydna; he argues that after $\mathrm{I}_{5} \mathrm{O}$, Rome no longer followed the rules of reason, "Political Morality and the Friends of Scipion, pp. 3, 4. Unfortunately, Walbank fails to apply any of his observations to the Iberian experience.

s Polybius offers four different Hellenic arguments concerning the destruction of Carthage; cited and discussed by Walbank, "Political Morality and the Friends os Scipion, p. 8 ff. Polybius also has Africanus say that the Romans cannot break treaties, for that is why they are fighting the Carthagenians, Pol. XV 4 , Ix; discussed by Volkmann, "Griechische Rhetorik oder römischen Politik», p. 474 .

- Rome's adamancy on deditio would contrast poorly with the projected picture of Rome, the benevolent conqueror. 
The annalistic tradition is best represented in the brief account of Livy's epitomator, Velleius Paterculus, Florus, Orosius, parts of Polybius and Strabo, and reflections of it in Appian and Diodorus Siculus. Here the Iberian tribes are depicted as a primitive and divided people, whose constant reversion to brigandage forced Rome into the role of a policeman protecting those Iberians who had been liberated from barbarism and had adopted Roman ways. Strabo, for instance, recounts with horror the primitive customs of the Celtiberians ${ }^{1}$. Florus relates the Iberian resistance as the frenzied flailings of a wild animal:

With much toil and sanguinary encounters (the Romans) taught submission to savage races who had hitherto been free and were, therefore, impatient of the yoke (133.17).

This "frenzy for independences" ${ }^{2}$ made them not only a fearsome enemy ${ }^{3}$ but it also robbed them of any effective leadership 4 , for the Iberians could simply not subject themselves to anyone. In the end Florus argues that although Iberia possessed tremendous resources, it never thought of pitting its combined strength against the Romans. In a similar vein, Orosius remarks that the Iberians were too won to their lives of idleness to vigorously press their war against Rome into Italy where it could be fought to their greatest advantage ${ }^{5}$. Even the courage of the $\mathrm{Nu}$ mantines during the notorius siege in $\mathrm{r} 34-\mathrm{I} 33$ is compromised by the assertation that much of their courage was provided by the use of a narcotic, called caelia ${ }^{6}$. Caelia, however, was not the only well-worn weapon in the Iberian arsenal. Again and again the Romans were confronted by Iberian duplicity - Roman garrisons were treacherously betrayed and massacred ${ }^{7}$. But one should not be overly surprised by the duplicity, for Rome was dealing with undisciplined brigands. Rome's presence was necessary to protect its Iberian allies from the roving. bands of neighboring bandits ${ }^{8}$. Not content with plundering, these brigands openly invited Roman intervention by their very insolence. Time and time again, these barbarian leaders shamefully insulted Ro-

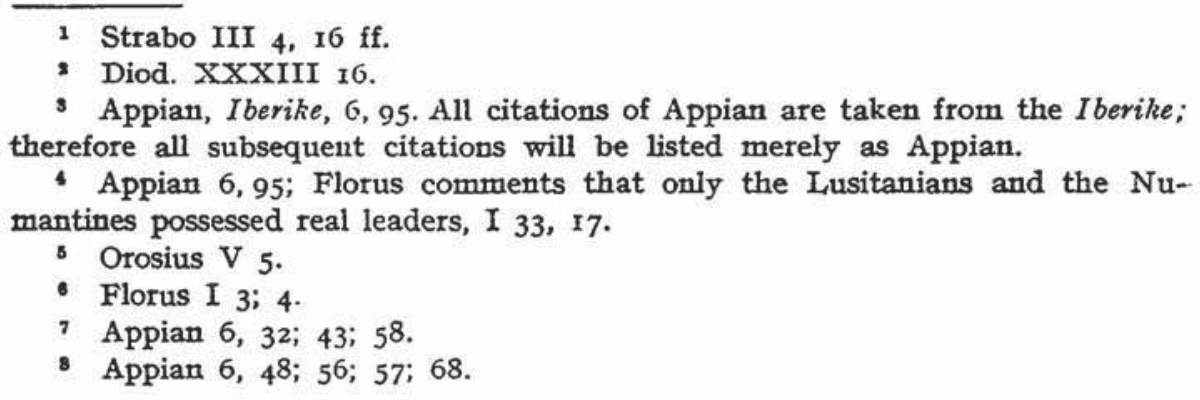


man commanders, thus leaving no response but crushing violence ${ }^{1}$.

On the other hand, the counter-picture of Roman efforts is unusually positive. It seems an annalistic characteristic that all could take pride in Rome's impressive beginnings in Iberia. Florus calls Roman behavior in this period ... pulcher, egregius, pius, sanctus atque magnificus... ${ }^{2}$. And no one could be more representative of these qualities than Scipio Africanus. His father and uncle had attracted many Iberian tribes to alliances solely on account of their individual uirtus, and the Iberians were understandably disconcerted at their deaths ${ }^{3}$. At Castax, Africanus waited until the pro-Roman faction gained the upper hand before actually taking the city, and in the wake of this subsequent victory left an Iberian in control of the city ${ }^{4}$. Following the Second Punic War, Rome shouldered its provincial responsibilities and dispatched praetors "... to keep the peace...»" .

The annalistic account of the activities of Roman commanders from Cato the Elder to D. Junius Brutus is quite brief, probably because there was so little to praise ${ }^{6}$. Cato is one of the few bright lights as an ideal example of the value of absolute deditio to both the conqueror and conquered alike ? Nevertheless, even the most brutish of commanders are excused and words of praise are drudged up for them ${ }^{8}$. Howe-

1 Diod. XXIX 28; XXXIII 24. The effect of all of this on a Roman audience must have been to convince them of the legitimacy of Roman endeavors and to leave them totally disdainful and apprehensive of the Iberian barbarians. Quite frankly urbane Romans must have been terrified by the stories of the savage ferocity of the Iberian that filtered back, and in such an atmosphere the stories of Roman recruiting difficulties would be quite comprehensible; e. $g$. Orosius 5 , 5. In addition, if Rome were to pursue a consistently tough policy on deditio, the masses at home would have to be kept in a constant anti-Iberian frenzy - the annalistic horror stories of the Iberians would of course do just that.

2 I $34,19$.

3 Appian 6, I6-I7

- Appian 6,32.

5 Appian 6, 38 .

- Florus is fairly indicative of this tradition - I 33, 17 .

7 Appian 6,39 ff.

8 Q. Servilius Caepio treats the Viriatic survivors well after their deditio Appian, 6, 75. C. Popilius Laenas was entirely justified in his attack on the Lusones - Appian 6,79. Justification can even be offered for M. Aemilius Lepidus' unprovoked and unauthorized attack on the Vaccaei and Pallantia Appian $6,80 \mathrm{ff}$. (One should note that the argmment offered here failed to convince Appian as well as the senate.) D. Brutus treatment of the Talabriga can be offered as yet another positive example of the practice of deditio, even though that war was also unprovoked - Appian 6,73. 
ver, even the most forgiving of the annalists could not ignore the repeated Roman failures on the battlefield. A great part of the glory won by Scipio Aemilianus was in erasing the shame of so many previous defeats ${ }^{1}$.

But of even greater interest is the anwalistic treatment of Viriathus, the Lusitanian folkhero, who led a highly successful resistance to Rome throughout the I40's. All the annalists agree that he was a shepherd turned brigand, who went on to become a guerilla leader ${ }^{2}$. Although respectiful of his successes, the annalists did not find Viriathus especially praiseworthy. Even Orosius, who is often swept up in spasms of national sentiment ${ }^{3}$, has little to say about Viriathus ${ }^{4}$. In fact, Florus claims that the Lusitanian leader was ready to quit, but the triumph-hunting C. Popilius Laenas forced him into yet another war ${ }^{5}$. Furthermore, Florus blames Popilius for arranging the assassination of Viriathus because he made it appear that Rome could only rid itself of such threats by acts of treachery ${ }^{6}$. Clearly Roman failures in Iberia were to be explained, not by Iberian successes, but by incompetent Roman leadership, and when Rome finally secured that leadership in Scipio Aenilianus, Iberian resistance was soon crushed. Therefore the resistance of the Iberians is repeatedly passed off as savage reaction against the refinements of a civilized life, while the Roman efforts are interpreted as a consistent defense of threatened Iberian allies against unruly hill tribes and brigands.

Polybius marks somewhat of a departure from this traditional atti-

1 Velleius Paterculus II 4, 2-3. The most shameful spectacle in those wars was the treaty secured by C. Hostilius Mancinus, and it seems that the humiliation spurred a search through the historical record to find a comparable disaster - the treaty secured after the defeat at Caudine Forks in the Second Samnite War, Vell. Pat. II r, 5; Appian 6,83; Florus I 34; Orosius V 7; thus indicating one effect of the Iberian Wars upon Roman historiography. For discussion of that subject, and references see Astin, Scipio Aenilianus, pp. 132, 206.

2 Orosius calls him a brigand who infested the roads $-\mathrm{V}_{4}$ Appian refers to the activity of the rebel leader in selling protection to local crop-owners - VI 64 . Appian also mentions other guerilla leaders who imitated Viriathus by raiding Lusitanian territory - VI $7 \mathbf{r}$.

3 See, for example, V 23.

$4 \mathrm{~V}_{4}$

8 I 33,17 .

- Ibid. 
tude. No longer need the Romans be as sensitive to Hellenic criticism ${ }^{1}$. Hard-headed pragmatism had to take precedence over fears of disapproval. Diodorus, who most probably used Polybius for the appropriate parts of his History, counsels:

Those whose object is to gain dominion over others use courage and intelligence to get it, moderation and consideration for others to extend it widely, and paralyzing terror to assure it against attack ${ }^{2}$.

For example in 152 , Marcellus recommended a treaty with the Aravacae, but its final ratification depended on the approval of the Roman senate. Rival embassies from the Aravacae and neighboring tribes, which were allied to Rome, appeared before the senate. Both sides presented their cases for and against ratification respectively, but what convinced the senators was the argument that although the treaty might be temporarily advantageous, if the Aravacae were not punished, Rome would face a flood of rebellions in Iberia, for this would be interpreted as a sign of weakness ${ }^{3}$. In other words, the weight of the issue hung not on fides to an ally, but on the long term benefit to Rome.

This cold-blooded Realpolitik is characteristic of much of Polybius' commentary on the Iberian Wars. Africanus was the first to institute such a policy, who with the Iberians first tried conciliation and when that failed used crushing force 4 . Rival commanders are judged by their merits as military leaders in a coldly objective way ${ }^{5}$. Such icy pragmatism even extends to Galba's action in Lusitania, whose massacre is criticized for being worse than that of the barbarians. But his greatest fault was to have needlessly prolonged the war ${ }^{6}$.

In a similar vein Polybius could not really blame cities that chose

1 Walbank reproduces an argument of Polybius that the Carthagenians had no complaints about Roman treatment after committing deditio - Political Morality and the Friends of Scipion, p. 9 ff.

2 Diod. XXXII 2. H. H. Scullard believes that this passage stems ultimately from Scipio Aemilianus to justify his destruction of Numantia without senatorial approval - «Scipio Aemilianus and Roman Politics», p. 73, n. 57.

8 Pol. XXXV 2, 3 f.

- Appian 6,24.

5 This is especially true of Viriathus. $\mathrm{He}$ is a worthy enemy of the virtuous Fabius Maximus Aemilianus and shows considerable foresight in victory - Appian 6,$65 ; 69$. Even though a barbarian, Viriathus showed the highest of qualities Appian 6,75. The Numantines are praised as first rate soldiers - Appian 6, 76.

- Appian 6,60-6r. 
to rebel against Rome ${ }^{1}$. According to him, the Iberians cooly reasoned that the best time to revolt was when Rome was occupied with the Celts and Philip $\mathrm{V}^{2}$. No, Polybius would not level criticism for carefully calculated revolts against Roman authority, but from that point on he demanded a committed and consistent resistance, even to the point of self-destruction. Polybius harshly handles a city which had resisted Philip V, because when they were finally defeated they balked at killing their own women and children rather than surrender ${ }^{3}$. How refreshing, then, must Polybius have found the requested examples of self destruction in the face of Roman conquest in the Iberian Wars 4 .

Such Realpolitik, however, proved difficult for some to swallow. Even Scipio Aemilianus was critized for his destruction of Numantia without awaiting the disposition of the senate ${ }^{5}$. A school of thought emerged that has been connected with Panaetius, P. Rutilius Rufus and most importantly Posidonius ${ }^{6}$, for the latter two certainly reacted

1 Walbank notes Polybius' argument that the Hellenic and Carthagenian leaders were insane in their resistance and means of resistance to Rome, but the insanity was based on the futility of the effort, not the merits of the effort itself - "Political Morality and the Friends of Scipio", p. II.

2 Appian 6, 39.

- Walbank, "Political Morality and the Friends of Scipion, p. II.

- The Saguntines destroyed their gold and their lives rather than surrender to the Carthagenians - Diod. XXV r5; Appian 6, 12. Such scenes were repeated later, but this time with Roman besiegers - see for example Appian 6, 33. While the enemy's self-destruction could be respected, it was even more imperative for the conqueror to leave a lasting impression of the folly of resistance; Gelzer discussed the wisdom of destroying major enemies and gives as examples Corinth, Carthage and $\mathrm{Num}$ antia - Nasicas Widerspruch gegen die Zerstörung Karthagosi, p. 65 .

5 Astin, Scipio Aemilianus, p. 153 f. Astin underscores this as indicative of the problems faced by Roman commanders in the field now having to make important diplomatic decisions, without having the time to await a decision of the senate. Appian 6,98 cites three different reasons why Aemilianus destroyed Numantia: Aenuilianus felt that it would be advantageous to Rome; Aemilianus was naturally vindictive; and Aemilianus believed that great calamities produced greater glories. The variety of answers all could reflect the contemporary debate produced by the act. In a previous incident Appian criticized Aemilianus for his negotiations with an Iberian chieftain, Avarus, commenting that Scipio with his virtue should "... spare a brave and manly race... $-6,95$.

6 P. Rutilius Rufus (34), RE, 1269-1280; Panaitios, $R E, 418-440$; Poseidonios, $R E$, 558-826; W. Capelle, "Griechische Rhetorik und römischer Imperialismus", Klio 25, 1932, p. 86 ff.; H. Strasburger, "Poseidonios on the Problems of the Roman Eimpire», JRS 55, 1965, pp. 40-53: A. Sclıulten, "Polybius und Posidonius über die iberischen Kriegen, Hermes 46, I911, pp. 568-607; Gelzer, "Nasi- 
in their histories to Rome's behavior in the Iberian Wars ${ }^{1}$. As in the older annalistic tradition, they felt Rome was justified in its expansion, but now it was for somewhat of a different reason. Rome had now to assume the role of benefactor ${ }^{2}$. The bitterness of conquest was soon to be turned into the pax Romana, which showered benefit on victor and vanquished alike. This was to be true, not only for Hellenes and Celts, but for Iberians as well. For example, Posidonius was able to illustrate the efficacy of this argument by pointing to the prosperity enjoyed by certain Iberian tribes living under Roman rule ${ }^{3}$.

However, what bound the Romans to this role of benefactor was a concept which seens to also heve been developed by the school of Panaetius - the concept of humanitas. It is to be sure a hotly debated term ${ }^{4}$, but for the sake of discussion it can be defined as the common

cas Widerspruch gegen die Zerstörung Karthagos", pp. 39-72; Walbank, "Political Morality and the Friends of Scipion, pp. I-16.

1 Both Rutilius and Posidonius were students of Panaetius, and both seem to have expressed many of their teachers' ideas in their histories, Cic., Brut. 114; de Off. III ro. Rutilius was actually at the siege of Numantia in $134^{-1} 33$, and is most likely the source of Posidonius' description, Gelzer, "Nasicas Widerspruch gegen die Zerstorung Karthagos", p. 47 ff.; Strasburger, "Poseidonios on the Problems of the Roman Empiren, pp. 4I-42. Of course neither source is extant, except fragments, and great difficulty comes in separating Posidonius - and through him, Rutilius - from the later sources, notably Appian and Diodorus. The problem is heightened by the fact that both Appian and Diodorus utilized Polybius for some of their narrative of the Iberian Wars. How does one separate the Polybius from the Posidonius? It is safe to say that for most of the material before 146 , Polybius is the primary source for both Appian and Diodorus, but after that date the question becomes more tangled. A. Schulten believes that Polybius remains the main source for Appian, even after 146 , because his geographical description of Numantia is so accurate that it must have been written by an eyewitness - "Polybius und Posidonios über Iberien und die iberischen Kriege», pp. 568, 570. This argument, however, ignores the fact that Rutilius was also a participant in the siege of Numantia and that Posidonius himself had visited the site of the battle. Schulten's argument also rests on the thesis that Polybius later extended his History with a description of Aemilianus' siege of Numantia, an assertion for which we have no extant evidence. The historian is then left to judge the tenor of the narrative after 146 by what is known about the philosophy of Posidonius and to compare Appian's account to that of Diodorus, whoin all would acknowledge relied primarily on Posidonius.

2 Volkmann, "Griechissche Rhetorik oder römische Politik», p. 469.

3 Strabo III 144; 154; 156 .

4 K. Büchner, "Humanum und humanitas in der römischen Welt», Stıdium Generale 14, 1961, pp. 636-646; A. A. T. Elırhardt, eImperium und Humanitas. Grundlagen des romischen Imperialismusn, Studinun Generale 14, I961, p. 646 ff. R. Reitzenstein, Werden und Wesen der Humanitat im Altertum (Strassburg, Heitz, 1907). 
positive qualities found in all men', and it was the responsibility of Rome to provide the atmosphere most conducive to the development of these qualities, whether the men were Hellenic academicians or Iberian tribesmen ${ }^{2}$.

And yet the irony contained within the development of this concept of Rome as benefactor is that Rome's behavior at this time bore little in common with the ideal of humanitas, and nowhere is this more true than in Iberia ${ }^{3}$. There one comes face to face with the repeated perfidy of Roman generals, the frequent collapse of military morals and the very disintegration of Roman society itself 4. Consider the Roman

1 For example Appian discusses the savage temper of the Numantines, but he also finds in their valor and love of liberty qualities to be esteemed by all men $-6,95$. Diodorus tells a queer story about $Q$. Pompeius Aulus and the Lagni. The Lagni received aid from the Numantines, but when they were threatened by $Q$. Pompeius they were quite willing to betray the Numantines. After taking the city, thanks to this act of treachery, Pompeius responded by executing the city nobles and sparing the Numantines. By an annalistic criterion this story is quite unusual, for it has something positive to say about the qualities of the Numantines and $Q$. Pompeius, an infamous homo nouos. For a discussion of Q. Pompeius see $4 \mathrm{I} 9$ and H. Simon, Roms Kriege in Spanien (Frankfurt, Vittorio Klostermann), p. 108 ff. Later Diodorus describes the suicides following the fall of Numantia and ccmments, *... even barbarians, brutelike in spirit though they were when fortune broke the customary bond between them and their native land, did not forget the fond affection for the soil they had reared - XXXIII 17: XXXIV 4.

2 For example, Appian notes that many Iberian tribes practiced brigandage because of poverty and that a proper and fair Rcmanization of the economy would remove that social ill cnce and for all - 1.100. See also Strasburger, "Poseidonios on the Problems of the Roman Empiren, p. 46 and Volkmann, "Griechische Rhetorik oder römische Politiks, p. $474 \mathrm{f}$.

3 Posidonius soundly criticizes Didius for using treachery to massacre the citizens of Colenda, an action certainly not unlike that of Galba's - Appian 6 , xox. See also Strasburger, "Poseidonios on Problems of the Roman Eimpires, p. 47. It is interesting to note that later Appian underscores the eventual punishment of the treacherous - Perpenna, who slew Sertorius, is limself slain by Pompey, the hero of Pcsidonius. This, of course, again suggests Posidonius as a major source for Appian 6, 101.

- For the perfidy of Roman generals see the footnote above. In addition Appian extends criticism to the Roman senate, which secretly encouraged Servilius Caepio to break the treaty previously secured by Sevilianus. This, Appian comments, was counter to the dignity of the Roman people. Although stemming from the anualistic tradition, Livy catalogues the horrors produced by the Iberian Wars; the consuls L. Licinius Lucullus and A. Postumius Albinus were thrown into jail by the tribunes for conducting a strict levy; there was a frightening lack of volunteers for the Iberian Wars, simply because the people had been terrified 
commanders of the Iberian Wars - men like L. Licinius Lucullus, Q. Servilius Caepio, Q. Pompeius, C. Sulpicius Calba and C. Hostlius Mancinus - men that not even the annalists could excuse for their incompetence and men that in the eyes of the Stoic school had outbarbarized the barbarians. The only relief on the Rome side from this continued tale of horrors was P. Cornelius Scipio Aemilianus, and even then Scipio seems to have disappointed some who had hoped for a display of humanitas toward the defeated Numantines. His behavior in I33 seems far more directed toward the approval of a Polybius than a Posidonius ${ }^{1}$.

No, there seems little to cheer on the Roman side for the spokesman of humanitas, but they are not without their champion. Curiously enough, however, he is an Iberian - Viriathus. Here is the ideal of the "noble savage". Certainly Viriathus had not received his education at the Academy - his learning had been in the hills as a shepherd. Nevertheless, he uttered gems of wisdom, remarkable in their simplicity and brevity ${ }^{2}$. Here was a man unimpressed by material riches, so honest that his share of the booty was equal to that of the rest of his troops ${ }^{3}$. Here was the general invincible in battle, but in victory so moderate that it eventually proved his undoing ${ }^{4}$. His qualities could be multiplied ${ }^{5}$, but the few listed need only be contrasted with tire Roman generals whom he faced. One would have to go back to $\mathrm{C}$. Fabricius to find a favorable Roman comparison ${ }^{6}$.

Now there can be little doubt that a great deal of the qualities of Viri:thus are the result of a stock characterization of the "noble savagen?. Those

by the stories of the fearsome barbarians - Per. 48. Scipio Aemilianus himsa if found it necessary to rebuild the army in Iberia before it could be used effectively against the Numantines - H. Simon, Koms Kriege in Spanien, p. $176 \mathrm{ff}$.

1 See above, footnote. Also see Strasburger, "Poseidonios on the Problems of the Roman Empiren, p. 49, on the disappointment of Rutilius and Posidonius over Aemilianus' destruction of Numantia.

2 Diod. XXXIII 7, 1,7 .

3 Diod. XXXIII 3; 7, 4; Appian 6,75.

- Appian 6,69.

5 See especially Appian 6,75 and Diodorus' description of Viriathus' wedding and funeral -33 .

- Scullard discusses the figures of Pyrrhus and Fabricius as a reaction against the nou sapientia of the young and the cynical in the middle of the second century, "Scipio Aemilianus and Roman Politics", 7.

7 Viriathus is superior in physical skills to other Iberians, while he was able to live off little food and sleep; he was always alert for any sudden activity Diod. XXXIII I, 2. 
historians who were concerned with the decay of Roman moral fiber could hold up Viriathus, an uneducated barbarian, as a biting criticism of contemporary standards ${ }^{1}$. In many ways the figure of Viriathus is nore significant as social commentary than historical biography. But is it not interesting that the most successful leader of the resistance that cost Rome so dearly would in turn be held up to them as a standard of moral excellence?

In conclusion then, in the middle of the second century one can begin to detect varying schools of thought on the role of Roman imperialism, and it is my contention that the lengthy Iberian Wars played an important role in sparking those changes ${ }^{2}$. I have discussed them within three broad categories, although one can see that there is considerable mutual dependence on one another. For example, the annalistic proclamations of Roman uirtus has much in common with the Stoic role of world benefactor for Rome. In the same light some of the harsh Realpolitik of Polybius could be accepted by the Stoic school, as long as its goal was to work for the eventual benefit of civilized men. Nevertheless, the differences are clear enough to indicate that the Iberian Wars provided an important motivation for the rethinking of Roman imperial policy, and in turn it indicates that the historian in considering the evolution of Roman imperialism in the second century must consider not only Hellas and Carthage, but Iberia as well.

RICHARD W. BANE

1 One need only contrast Viriathus with his contemporaries, the decadent oriental monarchs - Diod. XXXIII 4; $5 ; 6 ; 12 ; 14 ; 15$.

2 Gelzer felt that Rome only began to deal with its imperialistic Weltanschau in the middle of the second century, but he does not consider the role played by the Iberian Wars in this self-reflection, "Römische Politik bei Fabius Pictor, p. $163 \mathrm{f}$. 